\title{
AN EMPIRICAL STUDY ON THE ROLE OF PRIVATE UNIVERSITIES IN HIGHER EDUCATION IN BANGLADESH
}

\author{
Mizanur Rahman Jewel ${ }^{1,}$ Muhammad Yeasir ${ }^{2}$, Md.Jakir Hossain ${ }^{3}$ \\ Senior Lecturer, Dept of English, Bangladesh International School, Riyadh, Saudi Arabia \\ Head of Academic Affairs, I-Center \& English Language Trainer, Dhaka, Bangladesh. \\ Chief Writer and Editor, Square Publications, Dhaka, Bangladesh,
}

E-mail: mizanbd781@gmail.com

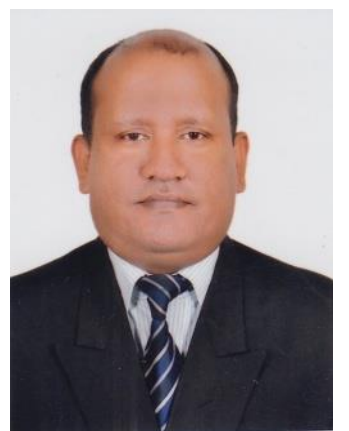

MiZANUR RAHMAN JEWEL

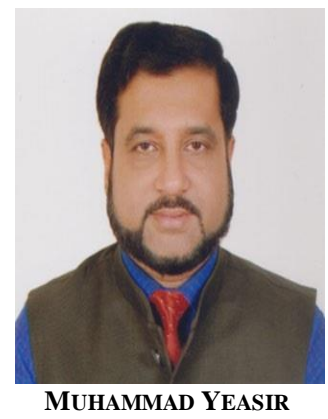

Keywords: Higher Education, Role of Private Universities, Nation-building, Innovation in higher education, job-market

\begin{abstract}
A B S T R A C T
Universities in Bangladesh play very important role in the overall development of the country. This is evident from the fact that the students and teachers of the Dhaka University which was established in the year 1921, was at the forefront of the national liberation struggle that led to the independence of the country. Other Universities of Bangladesh at both public sector and the private sector are also playing an important role by not only providing degrees and thus producing quality human resources for various sectors of the economy, but also producing enlightened citizens and thus improving the quality of life in the society as a whole. In order to solve the problem of accessibility of higher education the government of Bangladesh is allowing the establishment of private Universities in Bangladesh from 1992. But nowadays there is a controversy whether the private universities are contributing to the nation or not. The present paper is an attempt to reflect on the contribution or role of private universities for the task of nation-building and reforming the education sector. The paper will also formulate shortcomings and provide recommendation to overcome the existing barriers. To collect data, one questionnaire has been developed for the teachers working in the private universities in the capital city.
\end{abstract}

Citation: Mizanur Rahman Jewel Muhammad Yeasir Md.Jakir Hossain (2018). An Empirical Study On The Role Of Private Universities In Higher Education In Bangladesh. International Journal of Advanced Multidisciplinary Scientific Research (IJAMSR ) ISSN:2581-4281 Vol 1, Issue 3, May, 2018, \#Art.128, pp1-8

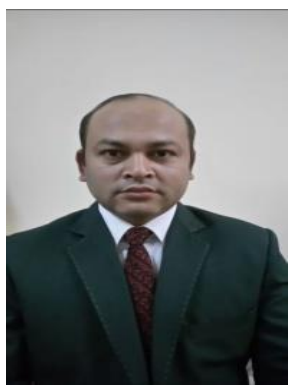

Md.Jakir Hossain 


\section{Introduction}

Education is the key to success, education make life meaningful. Receiving an education is one of the foremost demands of life. In Bangladesh, now there are two trends of higher education- public universities and private universities. Public universities are the oldest and ancient mode of education in our country, whereas the private universities are very recent one. Now public and private universities are working side by side in higher education set-up. But the common fact is that, there is almost no doubt and controversy about the quality of higher education imparted by public universities. They have, from the very beginning, created respectability to the scholars, students, and teachers and in the people in general. On the contrary, private universities are also doing the same thing- imparting education at an affordable and minimal cost. Despite the fact, there is a general and a commonplace tendency to ignore the quality of education provide by provided by private universities. Considering this fact, we made a research to find out the role of private universities in higher education in Bangladesh.

\section{Objective of the Study}

- To trace the evolution of different facets of institutional systems of higher education in Bangladesh.

- To Find out the governance, management and administrative problems of existing private universities in Bangladesh

- To suggest areas of action that need immediate attention.

- To formulate an opinion about the quality education in private universities.

- To bring into light the role played by the private universities in ensuring higher education in the country.

\section{Methodology of the Study}

One common questionnaire was designed to elicit information on the contribution of private universities in Bangladesh. The questionnaire included 14 questions on various aspects of contribution of private universities like-job market, learner's satisfaction, academic environment, session-jam and quality of the existing teachers. Open-ended and close -ended questions were used. The respondents of the survey were also allowed to pick more than one option (for preferred types) wherever necessary.

\section{Participants:}

The participants included 34 teachers from leading private universities of Bangladesh. The universities are integrated:

- $\quad$ The Millennium University (TMU)

- Southeast University (SU)

- Stamford University (SU)

- State university of Bangladesh of Bangladesh (SUB)

- Atish Dipankar University of Technology (ADUST)

- $\quad$ Asian University of Bangladesh (AUB)

The respondents of the survey were

- Teachers from English Department.

- Teachers from Business Department.

- Teachers from CSE Department.

The teachers were all instructors different existing private universities of Bangladesh .They were teaching both at graduate and postgraduate level. Noteworthy to say, that most of the teachers were professionally experienced and has been working in the private universities on a general range of 1-5 years.

The respondents were selected on the basis of merit and professional /excellence, especially those who common general knowledge on the private universities and knowledgeable about the circumstances, academic environment, course curriculum of private universities.

\section{Procedure:}

The respondents were given the questionnaire to fill out anonymously. The teachers' responses were collected within three working days. The students were given the questionnaire after class session and were requested to respond to report.

\section{Literature Review}

Providing university education in developing countries, unlike the developed countries was a responsibility always shouldered by the state. 


\section{International Journal of Advanced Multidisciplinary Scientific Research (IJAMSR) ISSN:2581-4281}

Country's first university, the Dhaka University opened its doors to the students in 1921. Until 1992, all universities in Bangladesh (total eleven) were in the public sector. The number of students seeking university education was quite few and there was no such thing as admission test, even till the late seventies. The education in the public sector was always public funded (tax payers). Often the cost of collecting fees was more than what was collected. With the passage of time the country's population (since 1971) doubled and the demand for education at all levels also grew. This was a very positive development and a country like Bangladesh, whose priorities in the education sector were more focused towards primary and secondary level, could hardly keep pace in satisfying the demand for university education. It was an absolute imbalance between demand and supply. Parents who could afford to send their children abroad did, often to third grade institutions. On one hand, there was a colossal drainage of hard earned foreign exchange and on the other hand many students returned with sub-standard education.

Realizing the problem the government enacted a private university law in 1992 allowing universities to be set up in the private sector. This was a revolutionary step for a country like Bangladesh. Through the establishment of NGUs, a homegrown reform agenda in higher education has been set in motion, and this indigenous approach is 4already producing good results in view of NGUs friendly attitude of successive governments under the existing benign legal framework.

Today, there are 55 non-government, universities delivering modern, market driven education through international cooperation, competent faculty and modern teaching methods. Since establishment, these universities have made significant contributions in terms of expanding the base of higher education in the country on the face of growing demand. According to the Annual Report 2008 of the University Grants Commission of Bangladesh (UGC), the number of students enrolled in different universities is $3,19,472$ (excluding students of National University and Bangladesh Open Universities). Out of this, $57 \%$ (1, $82,641)$ students enrolled in NGUs and $43 \%$ (1, 36,831 ) in the public universities.
Private universities offer programs on subjects that have demand in the job markets. The most popular is BBA, MBA, CSE, ECE, EEE, Pharmacy, LLB, LLM, English, BTE etc., AUST and UAP are offering programs in engineering. The private universities have been following the North American curricula, semester, and continuous system of evaluation of students. High quality audio-visual equipment, multimedia and practical approaches are used in teaching. Courses are offered mostly in the English language given the importance of the language in a globalized world economy. Computer skills and the use of application of computer softwares in solving problems and model buildings are emphasized in all programs.

Debating, writings and published by the students are normal features along with cultural activities. Some of the universities have programs to put students to stay in rural areas and write reports on how to solve problems of the society. Needless to mention, that most of the private universities have invested heavily in IT infrastructure and Internet opening avenues for students to learn from the millions of data, information. This is one of the reasons why per capita expenditure in private universities for students is somewhat higher.

Private universities are producing much needed highly skilled manpower for the country. Many of these graduates are employable both locally and internationally. Number of students going to foreign countries have decreased saving a huge amount of foreign exchange. They contribute substantially to national development. The importance of world class private universities will increase further in future. Without private universities, national demand for higher education cannot be met. Both public and private universities must coexist to supplement and complement each other. A strong partnership is desirable. However, one must note that of the 54 universities only a small number, including NSU provide world class education. None of them have fulfilled all the conditions of the Private Universities Act 1992 except NSU, which has constructed the 12, 50,000 square $\mathrm{ft}$. Magnificent campus building at Bashundhara. Therefore, it is absolutely essential that the government/UGC apply an effective supervising and monitoring mechanism that 
will ensure acceptable quality of education imparted by all private universities. In addition, there must be a regulatory agency like an internationally recognized Accreditation Council for quality assurance.

Private Universities opened up huge employment opportunities. The remunerations of university teachers also went up substantially. This enabled many academics to return home and teach. Private tuition and coaching system must go. This has corrupted the entire educational system. The deficiencies of students in some areas of the courses or subjects should be taken care of within the school and college systems. The teachers doing the extra courses scheduled by the Institutions should be remunerated within the system. Any teacher found to indulge in private coaching and giving out question papers must lose his job.

\section{Result \& Discussion:}

Role of Private Universities in Higher Education:

All the respondents respond positively to the first question to say about the role of the private universities. The responses given by the participants are summarized below:

- Private universities have opened- up a new window for higher education.

- Its flourishment is necessary for the national growth \& development.

- Private universities are booming in Bangladesh become public universities do have limited space in comparison with the growing / increasing number of students.

- The total duration of study in private universities is comparatively low in term of completion of degrees.

- Prospective candidate / students can enter into the job market very quickly as there is no session-jam in private universities.

\section{Quality of Education in Private University}

Maintaining the standard of quality education is said to be the first demand of private universities in the country. And obviously there are many arguments and debate about this topic. But in our research, we have found that most of the respondents believe that the private universities are maintaining this standard.

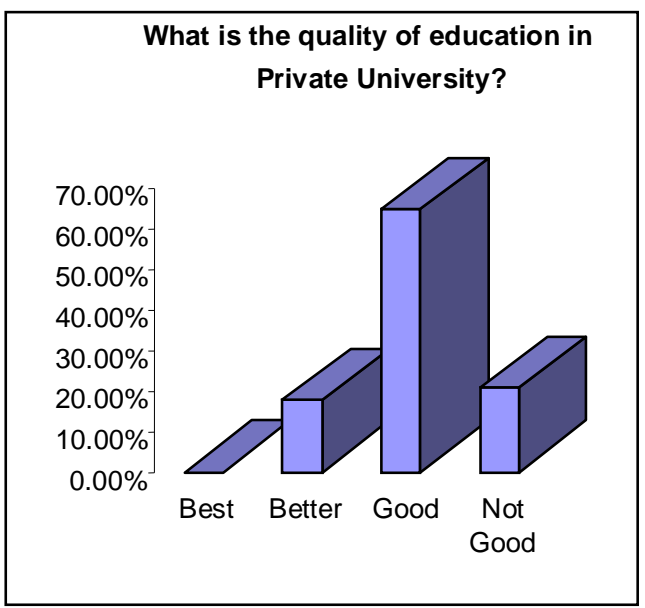

$64.71 \%$ respondents said that the education system of private universities is satisfactory. On the other hand $20.59 \%$ respondents said that the education system of private university is not in satisfying level.

\section{Curriculums followed by the Private Universities:}

Private universities are following a realistic and up-to-date curriculum in various disciplines. It is said that the universities are introducing subjects and academic disciplines in line with the twenty -first century demand. They are trying to provide the learners with the education that is said to be utilitarian and have a pragmatic value in their real life. In our study, we found that 80 percent teachers believe that the curriculums followed by the private universities are realistic and is consistent with current market-demand. 
https://doi.org/10.31426/ijamsr.2018.1.3.128

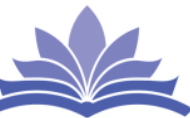

I J A M S R

\section{International Journal of}

Advanced Multidisciplinary Scientific Research (IJAMSR) ISSN:2581-4281

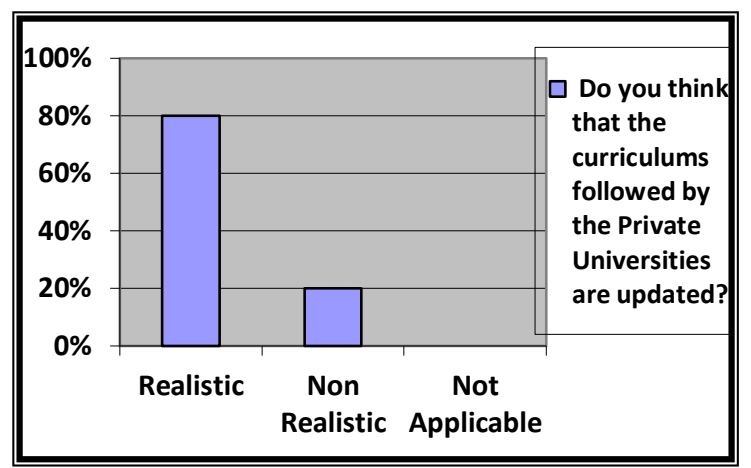

\section{Grading System:}

$52.94 \%$ respondents are of the opinion that all private universities in Bangladesh must follow a uniform grading system. On the other hand $26.47 \%$ respondents said that all private universities in Bangladesh should not follow a uniform grading system.

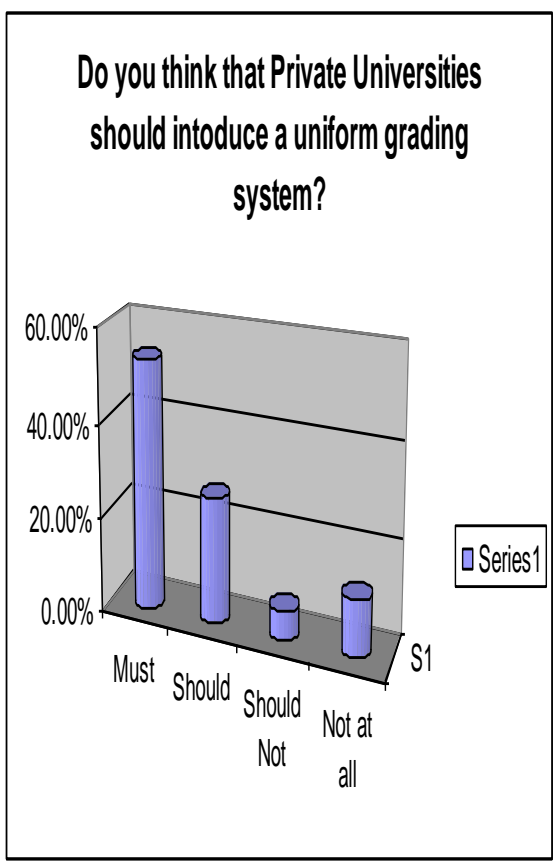

\section{Extracurricular activities}

Private universities are not only providing education at a minimal and affordable cost, but also opened-up a new avenue for cultural nourishment of the learners coming from varying strata of the society. All the (100\%) respondents are of the view, that their universities are engaged with various sorts of extra-curricular activities like-

- Debate competition

- Cultural exchange program

- $\quad$ Publishing newsletter, magazines.

- Arranging annual picnic-program

- $\quad$ Sports of different types, etc.

Application of modern technologies in the classroom:

We wanted to see whether the teachers and students of private universities use modern technologies. $80 \%$ of the total respondents were imperative to this question. We found out that most of the private universities are equipped with modern technologies like computer, internet, and power point project. And likewise, the classrooms are also decorated with modern IT facilities and as a result the students are receiving an education like western countries with modern fast eaters and equipment.

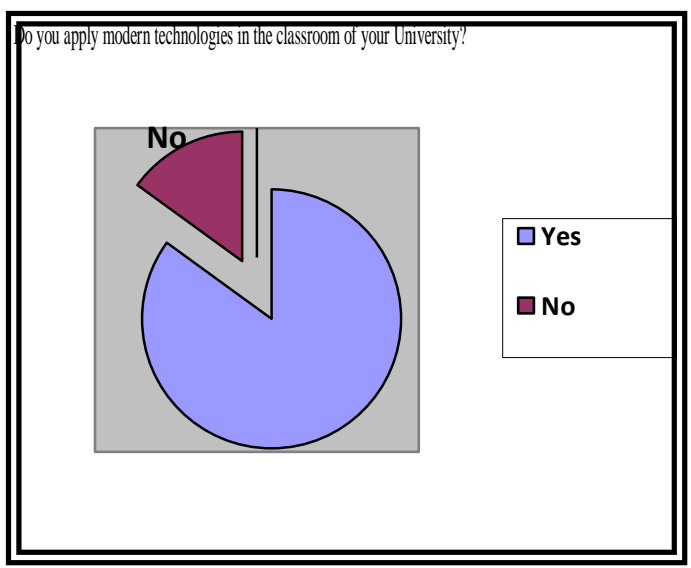


The positive sides of Private Universities:

Private universities have many positive sides.

The points found in the survey are summarized below

- Private Universities are providing opportunities for students who do not get scope to take admission in Public Universities.

- Syllabuses are realistic and up-to-date.

- Providing education at affordable cost

- There is no session-jam in the private universities.

Introducing the uniform admission test for enrollment:

On this question, $85.29 \%$ respondents said that all private universities in Bangladesh should introduce a uniform admission test for enrollment. On the other hand $14.71 \%$ respondents said against his question. Taking the admission - test will ensure the standard and merits of the students. And at the same time, it will encourage competitive outlook to the students for admission.

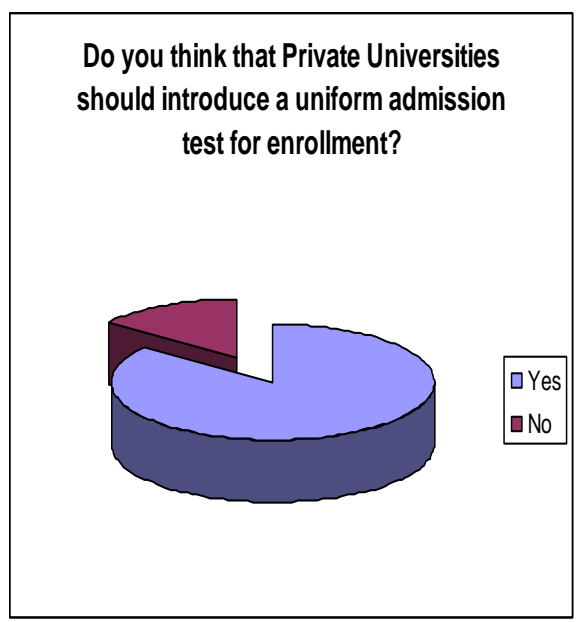

Do you think that after completing the education the students can make them successful in the job market?

\section{Success in job market:}

Students receiving education in private universities are also becoming effective and competent human resource in their professional life. The study proves that the students of private universities are equally getting a job like the students of public universities. They are playing their roles in administration, in BCS Exam, in multinational companies, in private sectors.

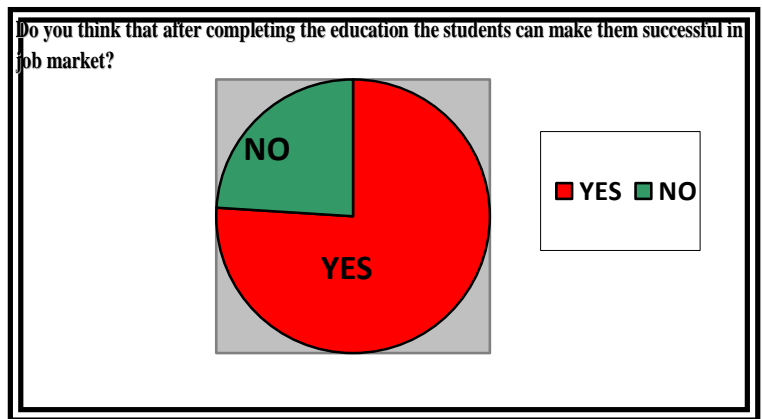

The students of Private Universities are enthusiastic for study

The students are being attracted to study at private universities. Since there is almost no session-jam in the private universities, it creates them unable to enter into a competitive job market in a comparatively less time than public universities.

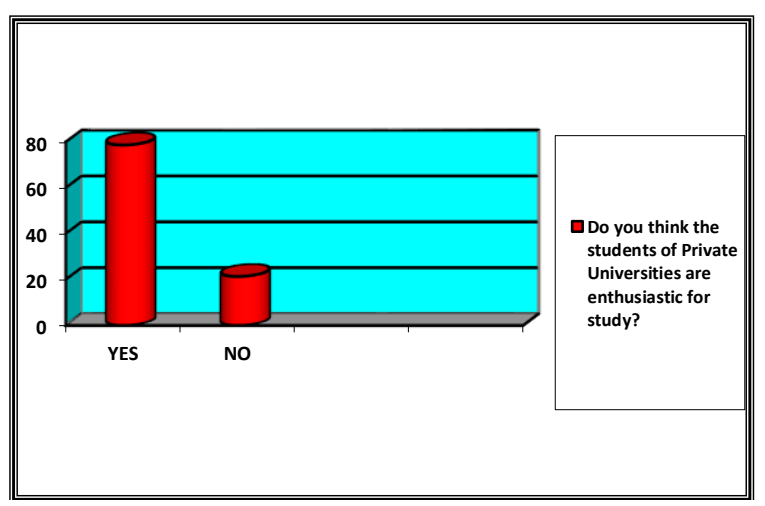


https://doi.org/10.31426/ijamsr.2018.1.3.128

\section{International Journal of Advanced Multidisciplinary Scientific Research (IJAMSR) ISSN:2581-4281}

$40 \%$ of total respondents are arguing that the general scenario the perception of students have changed about studying in private universities.

\section{Introducing $\mathrm{M}$ Phil, $\mathrm{PhD}$ in Private Universities:}

Introducing $\mathrm{M}$ Phil, $\mathrm{PhD}$ may enhance the level of standard and education of private universities. Moreover, it will provide students and teachers undertaking research in various arenas of academic pursuits.

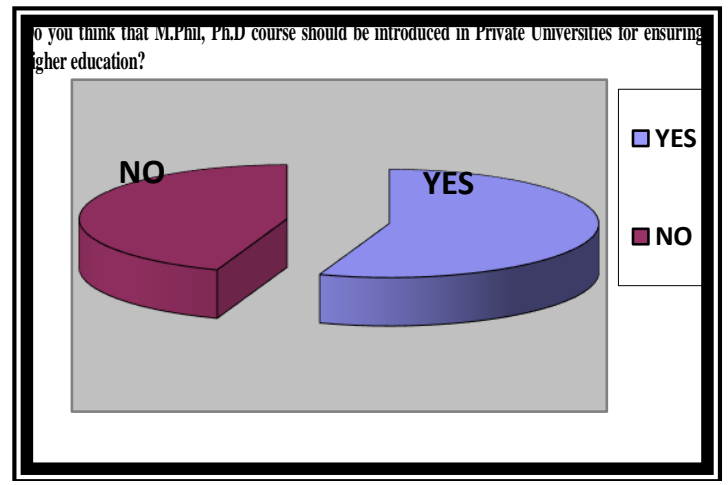

Research opportunities in Private Universities

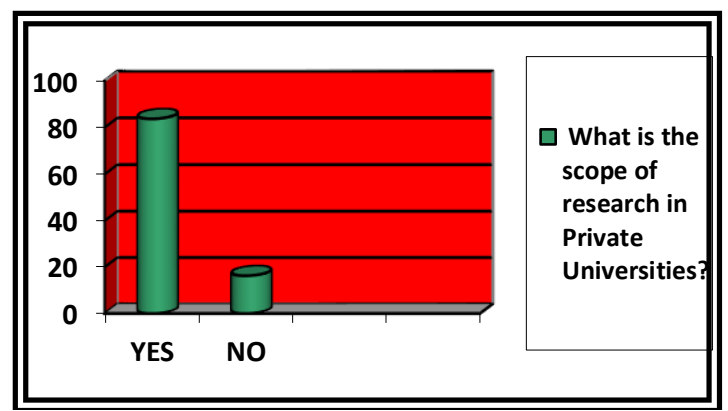

Private Universities are also in march of research activities at the time with the public universities. Most of the private universities now publish academic research journals, organizes seminar, symposium, conferences on various thematic issues for the students and teachers.

\section{Fixing up tuition fees:}

Total respondent of our survey was 34. In this question, 91\% respondents gave an opinion in favor of fixing-up tuition fees for this student. On the other hand 9\% respondents said against fixing-up tuition fees.

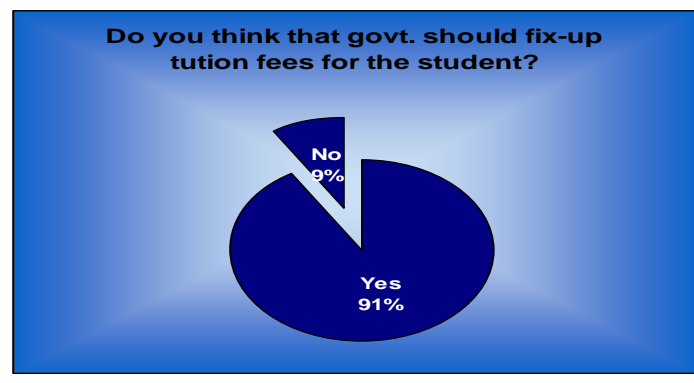

\section{A uniform salary system for the teachers}

In this question, $85.29 \%$ respondents said that a uniform salary system should be introduced for the teachers. On the other hand $8.82 \%$ respondents said against this question. And $5.89 \%$ respondent does not answer this question.

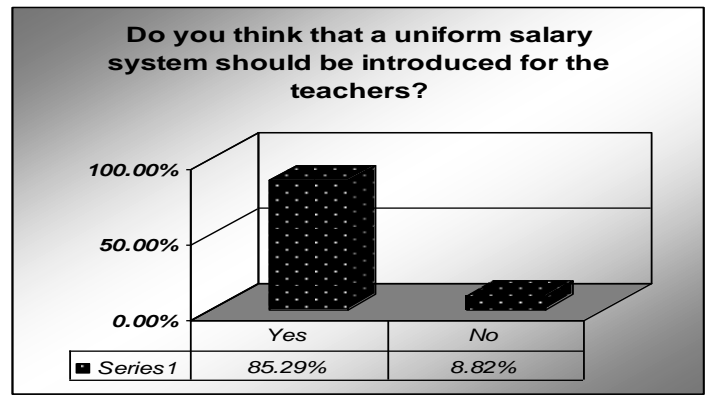

\section{Recommendation of the Research}

Considering the rapid growth of private-sector universities over a period of only 15 years, there are areas which need immediate attention by the providers and policymakers to improve service quality and to take these institutions in the next phase of development:

- Formation of an accreditation council composed of representatives of universities and faculties, regulatory bodies and other stakeholders. Recently, there has been talk of forming such a council under the auspices of the UGC (University Grant Commission). 
- More resources should be made available by the university, government and development agencies for the purpose of higher education and the training of faculty. International and regional academic institutions can extend assistance in this regard to help young academics.

- To be fair to students and parents, universities should not charge exorbitant fees to the students for the purpose of future university development and growth. Instead, each Board of Governors should mobilize others concerned, and raise expansion funds through donations or commercial borrowing.

- In general, the universities should have a quality-control mechanism in place for admissions and subsequent processing of students, and adhere strictly to it.

- Proper career counseling and job placement are recipes for a program's long term success, and successful branding of best educational providers. Each university should focus attention on this vital issue.

- Collaborative efforts with foreign universities and other academic institutions demand much greater emphasis to be effective. The opportunities for regional collaboration should be explored further, which could be more effective and less costly for each.

\section{Conclusion}

In this paper, we tried to find out the contribution of private universities in the arena of higher education in Bangladesh. The encouraging discovery was that truly, the private universities are contributing significantly in the higher education scenario in Bangladesh. On the contrary, the most prevalent shortcoming that was found out is that, some of the universities have limitations in flourishing fully the academic scenario and do not have a policy for teachers' remuneration. Despite some limitations, through the study, it has been come out that private universities aresignificantly playing key-role in the expansion of higher education in the country.

\section{References}

1. http://www.thedailystar.net/campus/2006/09/03/priv ate.htm)

2. Alam, M., Haque, M. S. and Siddiqui, S. F. (2007). Private higher education in Bangladesh. Research papers. Paris: International Institute for Educational Planning.

3. www.ugc.ac.lk/downloads/annual_report/UGC\%20A nnual...

4. Aminuzzaman, S. (2007). Overview of quality assurance in the context of Bangladesh Paper presented in a workshop organised by American International University Bangladesh, Dhaka, Bangladesh.

5. Andaleeb, S. S. (2003). Rejuvenating the Nation's Higher Education System. Proceeding of the workshop organized by International University of Business Agriculture and Technology, Dhaka, Bangladesh.

6. Cornesky, R. (1991). Implementing total quality management in Higher Education.Madison, WI: Magnar Publications.

7. Further Education Unit (FEU). (1991). Quality matters: Business and industry quality models and further education. London: FEU.

8. Gordon, G. and Partington, P. (1993). Quality in higher education: overview and update. Briefing Paper 3. Sheffield: University Staff Development Unit, University of Sheffield.

9. Hart, C and Shoolbred, M. (1993). Organizational culture, rewards and quality in higher education. Quality Assurance in Education, 1, 22-29. 